Acta Universitatis Sapientiae, Philologica, 8, 1 (2016) 7-28

DOI: 10.1515/ausp-2016-0001

\title{
Conflicting Narrative Identity Formation in Racialized Intercultural Discourse Nadine Gordimer's The Conservationist - A Cognitive Narratological Approach
}

\author{
Zoltán ABÁDI-NAGY \\ University of Debrecen (Hungary) \\ Institute of English and American Studies \\ abadi-nagy.zoltan@arts.unideb.hu
}

\begin{abstract}
The paper addresses the issue of how racialized intercultural relations can problematize the formation of narrative identity. How it can call in question the narratability of racialized subjectivity and lead to conflicting narrative identites of the same character as inferrible from narratorial discourse, vis-à-vis the way the character views itself in its intramental activity. And how all of this follows from, and is traceable through the manifestations of, racialized cognitive architecture, and thus, paradoxically, unnarratability can become the source of narrativity. The conflicting nature of racialized subjectivity and narrative identity formation will be examined, then, through a socio-cognitive lens. This study will draw on Nadine Gordimer's apartheid-era novel, The Conservationist (1974) as a tutor text and will be informed especially by colonial/postcolonial theory, cultural as well as cognitive narratology, cognitive cultural studies, theories of intercultural communication, and discourse analysis.
\end{abstract}

Keywords: apartheid literature, cognitive narratology, intercultural discourse, Nadine Gordimer, narrative identity.

\section{Introduction}

The main character, always in focus in Nadine Gordimer's apartheid-period narrative The Conservationist (1974) is Mehring, a middle-aged, rich white industrialist, the director of an investment fund and a member of more boards of directors than he cares to keep count of, who - although he is not a farmer - buys himself a farm on the money he earned in industry. He does it "to make contact with the land" and "as a sign of having remained fully human and capable of enjoying the simple things of life that poorer men can no longer afford." It is a 
"weed-choked, neglected" farm, "a dirty piece of land, agriculturally speaking" $(1978,22)$. For tax reasons he could have left it "misused or wasted," but he decided to stop "the rot," clean up the place, make it productive $(1978,23)$. Although he has an experienced black foreman, Jacobus, who runs the farm and manages the black farm workers with great skill, Mehring is the farmer, the boss. He thinks he has "to keep half an eye (all he could spare) on everything" (1978, 23). He is open to learning new facts, ready to cope with the new situation since this is what industry required from him in the city after all: he was "accustomed to digesting new facts and coping with new situations" $(1978,23)$.

But is he open to learn, is he ready to cope with the situation, really? What the Transvaal countryside has in store for the central character of this apartheid narrative in terms of human environment - the Afrikaners-alias-the-Boers-aliasthe Dutch, the Greeks, the Asian Indians, and especially the native black Africans (even if safely segregated in "the location") - both irritates and confuses him to a greater and greater degree. All this on top of a leftist mistress, Antonia, whom he helps to flee abroad $(1978,264)$, and a son, Terry with "well-meaning, if halfbaked, social conscience" (Smith 1993, 50), with whom the generation gap could not be wider (add a divorced wife, who is an insufferable nuisance to him).

So the more we get to know of Mehring, the less we know who he is. And he has the same problem with himself. Thus the novel is gradually developing into a journey, which is his quest for self-definition although, puzzling as it is, he could not be more solidly defined than he is - by the racial and social position that he occupies and the ideological conformity he represents in apartheid society. He is "a fundamental pillar of the oppressive system in South Africa" (Clingman 1990, 209). What we have as his story unfolds are more and more messed-up relationships: interpersonal, interracial, intercultural disengagement, and contrived or cut-off communication in all of these respects.

The author decided not to help her reader. As Nadine Gordimer made it plain in the Jannika Hurwitt-interview, in The Conservationist "you have a real narrator," "with a totally dispassionate view from outside," but the book is predominantly an interior monologue (Mehring's for the most part, but not always), and the line between when Mehring is speaking and when he is not "is very vague" (1990, 147). Although the dispassionate narrator clearly, though implicitly, represents Gordimer's antiapartheid stance (much-discussed in Gordimer criticism), and in various ways it is Mehring who is in the explicit or implicit focus of the intramental and intermental activities ${ }^{1}$ of the other characters too, narrative comprehension does take considerable effort on the part of the reader. The reason why habitual narrative-comprehension mechanisms fail us is the vague line just mentioned:

1 Theoretical concepts coming from cognitive narratology like "intramental activity" and "intermental activity" will be much more useful for us than "interior monologue" and "dialogue" since the whole novel is cognition - chiefly Mehring's - after all. 
the presented intramental activity "jumps about from different points of view" in the book (Hurwitt 1990, 147). "I chose to ignore," Gordimer admits, "that one had to explain anything at all. I decided that if the reader didn't make the leap in his mind, if the allusions were puzzling to him-too bad" (Hurwitt 1990, 148).

When leaps in our mind are needed to yield clues to understanding a narrative, narrative coherence is accessible through inferences. The latter are what Gordimer's leap-in-the-reader's-mind idea translates into. Constructionist theory of inference generation distinguishes local and global coherence inferences as well as explanatory and communicative ${ }^{2}$ ones (Graesser, Singer and Trabasso 1994, especially 375-376). The allusions that trigger those inferences can be overt, but in this case are more characteristically covert, embedded in the narrative discourse, which is to say: they are implied. It is so because the true nature of the society the novel is about must "reveal itself," Gordimer argues in the Pat Schwartz-interview: "The suffering inflicted by White on Black, the ambiguities of feeling, the hypocrisy, the courage, the lies, the sham and shame-they are all there, implicit. If you write honestly about life in South Africa, apartheid damns itself" (1990, 83; emphasis in the original).

\section{Racialized Cognitive Architecture: Intentionality}

The Conservationist invites us into Mehring's and other characters' cognition, their intramental and intermental activities, then. Thus what we have to engage, when trying to make sense of this narratively organized discourse, is the basic source and container of the cognition of the novel's fictional minds (and ours): their (and our) cognitive architecture. The many kinds and formalized models of cognitive architecture aside (from neuroscience and cognitive psychology through artificial intelligence), for narratological purposes cognitive architecture is "the range of databases" in our mind that are affected by new information, our "knowledge stores" (Zunshine 2006, 48-49). The attempt to interpret Mehring's fictional mind is also to examine the cognitive architecture behind his cognition, by the light of our own. We try to interpret his by mobilizing our own. It is in his cognitive architecture, where we can find what makes a mentality like his tick; where we can also hope to discern clues to some of the allusions Gordimer talks about. And it will be the hidden allusions, together with what triggers them, on what we can draw our inferences regarding the baffling phenomenon Mehring is. Antiapartheid Gordimer's method of presenting apartheid society in the fictional

2 The last one (the "communicative exchange between reader and author" - Graesser, Singer and Trabasso 1994, 376) is conceived in the present paper as modified by psychonarratologists Marisa Bortolussi and Peter Dixon, to mean communication between the narrator and the reader, and not the author and the reader (Bortolussi and Dixon 2003, 16). 
universe of The Conservationist makes it possible for her to condemn that society implicitly, i.e. without making her objective narrator judgmental. She described the method to one of her interviewers in simple terms: "I thrust my hand as deep as it will go, deep into the life around me, and I write about what comes up" (Schwartz 1990, 83). But she writes about it in such a manner that judgement is left, through the allusions, to the reader's ability to infer. Apartheid will then fall to the ground by its own weight.

If - to borrow and extend Gordimer's metaphor - we thrust our metaphorical hands deep into the novel, what comes up is a man whose narrative identity is both a solid logical product, constructed by the apartheid social environment and - for the same reason - an identity falling apart before our eyes until he becomes totally dysfunctional in terms of interpersonal and intercultural communication. Socially, he is a successful industrialist. Innately, he is not a bad human individual. Yet he is a dismal failure socially too, to such an extent that Mehring, the boss who lords over everything, ends up on the ground, physically and in a moral sense, with an apprehension that he will be killed in the next moment and will not even know why. Is his whole problem - and it is now readerly inference - ignorance? Failed identity formation (another readerly inference)? A failure that does not know itself? Or rather, a failure that does know, but does not want to acknowledge itself? As Judith Levy suggests, "Mehring is already a dead man, but he does not know it. Or at least that knowledge is kept at an unconscious level as 'unwelcome knowledge”' (Levy 2006, 108)? My suggestion below will be that he does know and is conscious of it, but is reluctant to act upon that knowledge.

So the reader thrusts his or her metaphorical hand into the novel and what comes up is a central personality, to whose identity we gain access through his own thoughts and recollections. But the protagonist does not see the first and most important aspect of his identity: the extent to which it has been claimed by apartheid, whose racist relational and communicative logic he internalized. While processing The Conservationist's narrative discourse as readers, we sense that we are dealing with two conflicting identities, then: one which develops through Mehring's narrative of himself, and one that the objective narrator develops about Mehring. How can we trace where we are with those two narrators, separately and vis-à-vis each other, and then, eventually, with the narrative subject called Mehring? We can trace it by examining Mehring's cognitive architecture by the light of our own knowledge stores, as the only way to recognize some of the allusions that Gordimer had in mind in the interview quoted above - and then by making our readerly inferences. Such an investigation involves, in turn, examining those two of the four levels of cognitive architecture that Patrick Colm Hogan calls the level of intentionalism (the character's goals, beliefs, intentions) ${ }^{3}$ and the level

3 "Intentionalism" as defined by Hogan and applied in this paper is not to be confused with Lisa Zunshine's "intentionality," a broader term which covers all declaired and concealed intentions 
of representationalism (the system of structures as well as mental processes and contents of the character's cognition; e.g. images of experience) $(2010,239)$.

"The portrayal of a particular mind-style can often be a major objective of a literary work (probably the major objective [...])," Catherine Emmott asserts, "and is important for the reader's overall interpretation of the work" (1997, 30; emphasis in the original). It is enough to look at the level of intentionalism in Mehring's cognitive architecture to realize that his mind-style is the clue to an overall interpretation of The Conservationist. But to draw up an inventory of the intentionalist domain of his mind only to prove that he is a racist tycoon and a misogynistic male - something that has been established about him by critics so many times (often rather one-sidedly) - would be superfluous and not to the point in the present context. Instead, let it suffice to quote some examples that would illuminate the point about the conflicting nature of the two identities: the protagonist's identity as he views himself as opposed to the identity that emerges from the objective narrator's discourse, and to how it is rooted in the intentionalist realm of the protagonist's cognitive architecture.

Mehring's beliefs and convictions spring from his aversion to, and disdain for, blacks, also for the Afrikaners/Boers/Dutch; and from the social position which makes it possible for him to buy whatever he wants to, especially property and women. His intentional thinking is fully racialized and sexualized. As Rose Pettersson puts it: he "ruthlessly exploits whatever and whoever comes in his way in order to achieve his own gratification" $(1995,91)$. His treatment of a girl on an airflight - Dorothy Driver's example - is totally “de-personalizing” $(1990,187)$. Not that his ruthlessness is that of a zealous backer of the apartheid, though. It is rather nonchalant. "[T]he Great Impartial” - these are the politically radical Antonia's condemning words; "[T]he politics are of no concern. The ideology doesn't matter" (1978, 82). Mehring nonchalantly accepts what an apartheid society has to offer a wealthy white male, not only in social advantages but also in racist clichés, true. Nonchalantly but not quite unthinkingly. He is intelligent enough to have apprehensions: "Soon, in this generation or the next, it must be our turn to starve and suffer. Why not?" - he is meditating, lying on the ground, with earth in his mouth (1978, 46-47). The bodily position is a reminder of the black stranger found dead, face down, in Mehring's third pasture and hastily and insensitively dumped into a shallow grave by the racist Afrikaner police but later washed up by incessant rain and flooding, as a symbolic reminder - a ghost that keeps haunting Mehring as it were. The murdered subaltern of postcolonial South Africa ${ }^{4}$ is haunting Mehring,

aimed at characters, readers by other characters, narrators, and authors. Zunshine distinguishes seven embedded levels of intentionality in a single Virginia Woolf paragraph (2010b: 206-207).

4 The racial institution of apartheid was established (in 1948) many years after the country had already been granted the status of a sovereign state (in 1934), thus, formally, South Africa was no longer a colony at the time the action takes place. 
the postcolonial colonizer - who "fails to realize that the colonial era has already come to an end" (Kathrin M. Wagner 1993, 84). ${ }^{5}$ But it is also an allusion to some dull, unconfessed remorse that does not know itself. It is the objective narrator's allusive device encouraging both backward-oriented and forward-oriented readerly inferencing. One, white minority rule denies black native majority land and life, Mehring being the foregrounded representative case in point - a backward-oriented inference. Two, the reader's forward-oriented inference that the dead man needs to be properly buried anticipates that he will be eventually buried decently by the blacks at the end of the novel, a concluding incident coded with significant meaning (about that significance later below).

But the predominant motives of the Mehring phenomenon, determining his cognitive architecture on the intentionalist level can be found in the multiple meanings of his being a conservationist. Two of these meanings/allusions are overt, both Mehring and the reader are aware of them. The third is covert and Gordimer (her objective narrator, that is) leaves it to the reader to work for it.

Firstly, Mehring is an avowed conservationist in the most common (and in itself conflictive) sense of environment protection: he wants to stop "the rot," clean up the land as I have already mentioned. Protection of the environment is a cause that he takes so seriously that, for one, he prohibits the farm workers' children to play games with guinea fowl eggs $(1978,12)$. He also refines that agenda to the point that it swings over into its own parody: "He is pathologically concerned with the conservation of the land, and he cannot allow himself to drop as much as a cigarette end on his farm" (Pettersson 1995, 94). But the real conflicting elements of the conservationist component of the environmental protectionist's narrative identity are not these; rather, it is how an oversensitive relation to the physical environment (the country, the continent, the oceans, the sky $[1978,11])$ is almost totally insensitive to what is happening to, and what he himself is doing to, the human environment. Insensitive on the level of routine intermental activities at least; ${ }^{6}$ intramentally it is a much more complex issue as indicated above and will be further elaborated below. Another - similarly overt - "conservationist" in him is the one that contributes to the conservation of the racist system, a characteristic that his conscientious-objector son, Terry challenges and his leftist mistress, Antonia castigates with scorn. As we have seen, Mehring has his apprehensions (of the blacks taking over one day, maybe),

5 This is the generally accepted view concerning Mehring, but I side with Lars Engle, who refines the point: "Mehring seems to imagine himself specifically defending industrialism against romantics who find it distasteful, rather than defending colonialism" $(1993,103)$.

6 Almost totally because we do see signs of his concern for others. He does manifest fatherly feelings for his son, not necessarily obstinate or wrong-headed in every respect. He does lend the Toyota pick-up to his unsufferable Boer neighbour, Old De Beer. He does give instructions to Jacobus to assist the dead man's reburial ("Jacobus must look after everything nicely") even if Mehring himself does not even want to hear about it $(1978,266)$. 
he is warned that he is a racist after all, he would even "make the world over, if it were easy as that" $(1978,81)$, and he does have racially-motivated survival reflexes (he turns his back on everything and runs in the end). However, the real clue to his mentality and the fundamental source of who he is, and therefore to the dual identity of this racialized subject is the third (covert) meaning of "conservationist:" he internalized (conserved internally) the ruling white elite's view of the apartness of racialized South Africa. What the narrative is doing here - as it is processing Mehring through his story, so to say - can be described with cognitive naratologist Manfred Jahn's flow-charting method ("an adaptation of Bremond's model"): the internalization of the external into an internal story, which is then externalized into an external story $(2003,201)$. In our context: it is the external (the racist apartheid world) internalized by Mehring which is then externalized as the Mehring-story, viewed both internally (through presenting his mental activity) and externally (by the objective narrator).

\section{Racialized Cognitive Architecture: Representation}

"Representation" is one of the key notions of postcolonial theory, and that theoretical idea is relevant in our case too. (I will take up that line later below.) As for the level of "representationalism" of cognitive architecture, it "systematizes our mentalistic idiom, developing it into a system of structures ('working memory,' 'episodic memory,' and so on), process ('memory consolidation,' 'memory retrieval,' etc.), and contents (e.g. particular images from one's past experience)" (Hogan 2010, 239). In order to make the subject manageable, we need to limit our enquiry into the representationalism-level of Mehring's cognitive architecture to what and how his mind stores of general knowledge and of his personal experience (the latter also forms part of his knowledge). In other words, what the representations of these would be in his knowledge system. The way we can access and evaluate Mehring's multi-component knowledge is - as has been indicated above - by confronting it with our own general knowledge of the world and with the way we, the readers store (i.e. represent) what Mehring experiences (both of his social environment in general and as personal experience as an individual in particular). The name of the game for the reader is comparing representations: Mehring's and ours. We can do this only partly on the basis of our own general knowledge of the world. We also need to rely on what we gather about Mehring's general knowledge of the world as well as about what his personal experiences are, and how he stores them. Our source regarding the latter (i.e. his mental representation of general knowledge and personal experience stored in his long-term memory as his knowledge) is what Emmott's narrativecomprehension theory calls the reader's "text-specific knowledge," - information 
"stored in the mental representation of a character" (1997, 7 and 19). For us, it is information that we gather from the text, as we process the narrative, about Mehring's representations.

Our text-specific knowledge does confirm what Rita Barnard establishes about how the pastoral that our industrialist protagonist hoped for when he bought a farm turns out to be an ironic one against an apartheid background. Apartheid did not "simply" marginalize black Africans; rather, it was a world of "forced removals" and brutal relocations of the black population whose civil rights were absolutely denied in the first place (2007, 71 and 76). The way the dead black stranger is shoveled in by the police without investigation, itself alludes to the total denial of rights. It is the rights of the native people and their right to live which are declared dead and are buried here symbolically. What makes the "misdirected pastoralism" - "the ultimate symbol of white capitalist corruption and alienation" (Kathrin M. Wagner 1993, 85) impossible is also that Mehring himself is racist. It is enough to look at his entity representation when he is first led to the dead man by Jacobus and first espies the corpse (the point of view is Mehring's): "One of them" $(1978,15)$. He does not call the people to whom the land belongs "blacks," not even in his thoughts. The denied other of the apartheid is just "they" and "them" for him. He is "incapable of seeing other (black) human beings in other than functional terms," Dorothy Driver notes (1990,190). Once it is as bad as this, it may not be going too far to suggest that foreman Jacobus, who does his best to balance between the master and "them" (Jacobus's own people) is introduced and referred to by Mehring as his "herdsman." It may be another indirect allusion, in which the cowherd is only one step removed from the black "herd" or "herdsman of the black" - keeper/manager of the black "herd," some of whom are Mehring's farm workers and all of whom live behind a barbed-wire fence on the "location."7

Mehring's intermental (actual and imagined actual) dispute, and to a much greater extent intramental (i.e. recollected) debate with Antonia and Terry open up a rich mine of representations. ${ }^{8}$ And here it is not the cliché that triumphs: Antonia's and Terry's representations as Mehring stored them in his mind are much more complex and sophisticated than Mehring's representation in their mind. They are the ones who break away from racist schemata and scripts (especially political activist Antonia does), yet their view of Mehring is clichéridden. (See the mental representation of the white industrialist's relation to the

7 Gordimer regarded apartheid much worse than even "colonial racism” (see her Gross-interview, 1990, 307).

8 It is also rich in metarepresentation. We "metarepresent" our representations if we "keep track of sources of our representations." It is "a particular cognitive endowment closely related to our mind-reading ability" (Zunshine 2006, 47). Mehring does keep track of the sources of his representations and keeps evaluating them. As for his lover and his son, he does not accept them as a source. The mental process that leads him to this decision is cognition about cognition, a representation regarding representation - i.e. metacognition or metarepresentation. 
land in Antiona's mind [1978, 176-178].) Mehring may be captive to much of the colonialist/apartheid mentality, and his contempt for scripts of convention may not go far beyond avoiding parties and new-year messages by not responding to people's phonecalls. And here, once more, we sense dramatic irony: the objective narrator winking at us from behind his protagonist's back because of the conflicting logic of such a behaviour. Yet, subconsciously, Mehring probably does feel that he accumulated some representational deficit in the racialized world and the reason for it is the very social side on which he stands. So he is trying to make up for some of it by conscious experience-acquisition when he lies down on the ground in the very position the black corpse was found lying - "his non-rational physical sympathy with the dead man" (Smith 1993, 50). Although this is itself a conflictive image as the objective narrator may also allude to the naive if not ridiculous nature of the moment on somebody's part who contributes to the blacks becoming social outcasts even if he is not promoting the ideology, apartheid being the largest and deterministic frame in South Africa between 1948 and 1994.

The circumstances of his desertion of the farm may also be ridiculous - and, for him, most humiliating - at the end of the novel, but the cognitive approach sheds a different light on it. The interpretation Mehring puts on the incident (a woman who may or may not have trapped him; a strange man, who may or may not want to rob, kill or castrate him [1978, 262]) can be seen as Mehring's inference, triggered by racist schematas and scripts. The Afrikaans-speaking man may have wished "to protect" him (as vice squad or a "guardian of the purity of the master race" [1978, 263]), but the incident brought Mehring to the end of his tether, because his inner representations tell him something else. Let me surmise that Emmott's contextual frame theory will help us out as for what that something else can be. "The 'contextual frame' stores information about which characters are co-present in which location at which time" in a narrative. And, besides overt participants, unmentioned participants can be covertly present in the same location at the same time (Emmott 2003, 304). I submit that the participant who is not present in the Mehring-scene is the dead black man.

The dead man is the most significant participant, who is not present overtly/ physically at this location at this time, but is co-present in our contextual frame, especially because Mehring himself links the disgraceful incident to that of the murdered stranger in his intramental reflections. He is suddenly paranoid and scared, not simply because "[t]hese are the bastards who shovelled him [the black corpse] in as you might fling a handful of earth on the corpse of a rat, just to cover the stink" $(1978,263)$. But also because his human decency gets the upper hand in him concerning the dead black man, and because he feels (probably also as a result of the inner representations yielded by his racial experience and meditations) that the time for his own burial has arrived, and these people are here to shovel him in, this time. Perhaps it is no exaggeration to say: apartheid 
caught up with Mehring at this point, the poetic justice part of it certainly did poetic justice meted out by the objective narrator. Justice is administered in the fashion we have already seen at work in the novel: through the allusive technique that makes readerly inference possible. The thought that crosses Mehring's mind that perhaps the time for his own burial arrived is an allusion, which implies (the reader infers) that Mehring is the stranger, metaphorically speaking (a stranger in the land of the many sub-Sahara black tribes of South Africa). The objective narrator makes us aware of how Mehring, who views himself as the triumphant industrialist now ready to learn how to be a good farmer is in fact struggling more and more flounderingly in the role in which he is positioned in the apartheid world. Mehring, the "the stranger" is doomed to death in a sociocognitive sense (because his social role is); and he (what he represents socially) is buried (symbolically) when the black corpse is buried. This does identify him, metaphorically, with the murdered stranger. Mehring, the colonialist-“stranger" is doomed to death, has been dying gradually as he realized it faintly and then more and more vividly, but now he is "murdered," figuratively speaking (turns his back on the farm, on the pastoral dream in apartheid hell and on his racist role in it). Our forward-oriented local inference, on reading the scene in question, is that he will try to get away alive. Our forward-oriented global inference is that black South Africa is moving towards liberation. After all, as Gordimer explained in the Hurwitt-interview, the funeral of the unknown man is a reburial when his own land receives him at long last ("he has now been put with proper ceremony into his own earth"). In other words, the "disguised message" of the "resurrection theme" is at work here $(1990,150)$, the resurrection of the black African in South Africa. In Stephen Clingman's words: "the raising of the black body simultaneously represents a 'return of the repressed' on both political and psychological levels” (1990, 208). But a backward-oriented global readerly inference, established by a network of allusions, can certainly take it one step further and indicate that Mehring was the dead stranger all through. The question was: how much intermental and intramental work it took for him to realize it too. The Conservationist is the process of that realization.

Memories and narratives are removed from previous experience, Mark Freeman theorizes, but they "still deserve to be considered real and potentially important as sources of information about ourselves and our past” (1993, 91). As his memories and representations are for Mehring. His memories are too many and more important than he believed them to be (his former strategy of willed noninvolvement and isolation fails). We can adapt Uri Margolin's phrase to describe what happens to him: what we are witnessing is "perceptual system shutdown or crash," where the mind is overwhelmed with impressions and our ability to decode them is reduced $(2003,289)$ - if by "perceptual" we mean mental perception instead of the physical. 


\section{Manifestations of Racialized Cognitive Architecture: Intra- and Intermental Activity, Positioning}

What is stored in the levels of intentionality and representations of Mehring's cognitive architecture as his knowledge that motivates his cognition is revealed in his intramental and intermental activity as well as in his positioning. We have already seen details illustrating how the intra- and intermental point, centripetally, to what Mehring's cognitive architecture contains as the source of those mental activities. But if we examine this relation from an inverse direction - i.e. intra- and intermental activity as manifestations of cognitive architecture - the reversed (centrifugal) perspective reveals features of Mehring's cognitive behaviour that would otherwise remain hidden.

What makes our conservative-conservationist protagonist a much more complex figure than those who seem to be progressive in thinking by comparison (Antonia and Terry) is that although we expect the political conservationist in him to be fully guided by his intentionality, and that he will live up to the requirements of his representations - in fact he cannot entirely, not in every respect. The realization dawns upon the attentive reader early as a forward-oriented inference. Mehring refers to the murdered black man as just "one of them" $(1978,15)$, as already mentioned. Yet, he instructs Jacobus in the closing sentence of the first chapter-like unit of the text, motivated by some innate humanness, to cover the dead man with something: "You'd better take something - to put over, down there. (His head jerks towards the river.) A tarpaulin. Or sacks" (1978, 21). True, he avoids to refer to him even as "him." Paradoxically, Mehring's reaction, once he has seen the dead man, is already an improvement on the initial colonial arrogance with which he related to the news when Jacobus first communicated it to him and he responded by asking: "Why should I go to look at a dead man near the river?" $(1978,13)$.

What our cognitive narratological approach helps us notice very soon is that Mehring's intramental and intermental activities (his recollections and meditations, on the one hand, and his interpersonal exchanges, on the other hand) do not go hand in hand. While intermentally he is a faithful representative of the socially constructed role racial discrimination prescribes for the Englishspeaking white boss (he wants to keep an eye on everything, to have his orders obeyed and detests black Africans), intramentally he is a realist too. Racist power discourse assigns him a place at the top, but intramentally he has no illusions: “They [the blacks] know everything about us" (1978, 57); "They have been there all the time and they will continue to be there. They have nothing and they have nothing to lose” (1978, 260). Intermentally he never uses the harsh tone with Antonia that she adopts with him, but intramentally he is right (the realist again) 
about how her kind of radicalism is shallow and does not take the world very far. In intermental negotiations he is often tough with his son, Terry, but intramentally he does cherish genuine fatherly feelings for him.

Mehring's mind "habitually runs" on a "fine criss-cross of grooves" $(1978,58)$. He senses a "gap" that "lies at a deeper level in the text than the undeniable truth of the white man's ultimate failure to possess the land." It arouses "terror in him, the sense of standing over an abyss" (Levy 2006, 113). Our context can refine the point further: the "fine criss-cross of grooves" of his mind makes it possible for him to confront his cognitive intentionalism and the representations of his knowledge systems with his experiential knowledge of the world. Thus he is engaging in a task which will be the reader's too, who, in turn, will compare Mehring's cognitive architecture with his/her own. The resulting slow process of transformation, is checked and qualified and barely discernable in his intermental activity. But he is indeed making steady progress intramentally, with the nameless black corpse as a concealed catalyst, until Mehring's subconscious and formless dissociation from his dream of colonialist pastoralism takes shape in his mind, overwhelms him and erupts from under the surface in that humiliating scene at the end of his story.

However, all this takes place inside Mehring. At this point one would expect the intramental and the intermental to be in full accord. But very few sentences are actually exchanged intermentally, no matter how radical the nature of Mehring's decision is. In what is a brilliant piece of writing, the clashing intermental confrontation between Mehring and the "thick-headed ox, guardian of the purity of the master race" $(1978,263)$ all takes place intramentally, in Mehring's mind (1978, 261-265). It is one of the many moments (but the most crucial one) of the intramentally presented intermental in the novel. It can also be seen as the intensively imagined intermental that effects a decisive change in the realm of the intramental.

And with this we have reached the problematic of positioning. The protagonist of The Conservationist is the embodiment of a paradox, therefore his position is paradoxical. Colonial-reflexed postcolonial apartheid is itself a paradox. That is the external that Mehring internalized, which internal story is then externalized as his story, mostly through his intramental activity as we have just seen. And his story is about how he has been positioned by this culture. ${ }^{9}$ But, as we saw earlier, he also develops dilemmas related to his position. The more closely he examines his alienating and alienated role, the more distressed he becomes.

The whole novel can be regarded as a narrative of position-discomposure - a novel of repositioning eventually. Gordimer called her central character "a kind

9 Our place in society depends on the role we take, Gordimer argues. We may run away from our "inevitable role," or we can "take it on." "But the fact is that you have a role; there is no such thing as an ivory tower - that's a place in itself. You are consciously or unconsciously creating a position in your society" (Gray 1990, 180). 
of fossil" in the Schwartz interview $(1990,80)$. And he is too, in that he is the walking embodiment of an outdated social establishment. An establishment that forces Jacobus, Mehring's black foreman into a seemingly easy-to-mold position, a good illustration of what Homi Bhabha described as mimicry.

Jacobus is a position-shifter depending on who he is dealing with. It is an existential imperative for him to do the job to Mehring's satisfaction; but he also does his best to help his own people on the sly side. Jacobus's positioning differs from the rest of the blacks. The latter are positioned by apartheid to be undesirable and oppressed aliens in their own country, ${ }^{10}$ but his positioning comes from Mehring, one character positioning the other. So his activity as a double narrative agent of the storyworld, i.e. serving Mehring, the white boss, but trying to help his black people too, means that in his intramental cognitive operations he rejects the positioning that comes to him from Mehring. "An ironic compromise," "the sign of a double articulation" is what mimicry is in Bhabha's definition; pretended accommodation, inclusive of its difference "that is itself a process of disavowal" (1994, 86). This makes Jacobus a skillful juggler of positions: he tells the black women "to warn the children not to collect eggs where they could be seen," and reassures his conservationist white boss that "there were plenty of guinea fowl about if you had to be up at work early enough to see them" $(1978,33)$. "[T]he discourse of mimicry is constructed around an ambivalence" after all (Bhabha 1994, 86; emphasis in the original). As for Mehring, he may be fossil, but he is certainly not petrified. We see him, as we read on, more and more as a man of “disjointed consciousness" - also Gordimer's words, this time from the Diana Cooper-Clark interview (1990, 225). In the cognitive narratological context of the present study we can say that what Mehring is experiencing is a widening rift between his position and his positioning cognitive architecture.

\section{Communication}

"[I]t needs to be made clear about cultural discourse and exchange within a culture that what is commonly circulated by it is not 'truth' but representations," Edward Said claims about culture and representation in general, adding: "there is no such thing as a delivered presence, but a re-presence, or a representation" (1979, 21; emphasis in the original). We have already seen the racialized level of such colonial representations in Mehring's cognitive architecture that bear the mark of apartheid. Thus what we find in The Conservationist is that it is also about the impossibility of intercultural communication in a de jure postcolonial but de facto colonial world of racial segregation. Communication is completely racialized

10 "What is South Africa?" Frantz Fanon asks. "A boiler into which thirteen million blacks are clubbed and penned in by two and a half million whites" $(1968,87)$. 
in the apartheid South Africa of Gordimer's novel. When group communication shifts from the intercultural to an interracial basis in a racist environment, interest in the - marked or unmarked ${ }^{11}$ - culture of the racial other is eclipsed.

A whole array of incidents and communicative details illustrates the following two points that appear to be the same but are different: one, interest in intercultural presence is killed by racist representations; two, meaningful interracial communication is made impossible by trivial and evasive communicative routines. To appreciate the first point (absence of intercultural presence), it is enough to realize that we cannot detect any genuine black African cultural presence in the storyworld-agents' communications. It is absent from the novel in every respect other than the objective narrator's indirect discourse (e.g. symbolic suggestions). ${ }^{12}$ As a matter of fact, any kind of preoccupation with the racial other's culture is totally absent all along the racial line, be it the English-speaking industrialist Mehring, the Africaner De Beer and his family, or the immigrant owner of the Indian store and his family. There is no sign of positive inter- or crosscultural engagement among them either. And they all have a contempt for blacks and black culture. Mehring detests the Afrikaners and keeps his distance from black Africans as much as he can. He is sharply aware of Jacobus's interracial agency: Jacobus serves the white man but also helps the blacks; Mehring lets "them" bury the murdered stranger if they want to - but he wants to have nothing to do with "them." Nor do his frequent travels to other countries mean anything to him culturally, no sign of cultural pursuits or memories concerning cultures outside South Africa (Japan, for example). Afrikaner De Beer does cherish history, but it is the Boer history of heroes of the Boer wars, prime ministers, politicians who implemented apartheid and signed their photos for him; not mentioning his own grandfather, who fought in the Kaffir Wars, and a "kaffir" doll ${ }^{13}$ the grandfather took from a Kaffir chief before they burned his place $(1978,54-55)$. Such details speak for themselves. But Mehring is full of uncertainties concerning his own "I" identity, both individual and personal, and his collective or "we" identity ${ }^{14}$ comes under fire from Antonia and Terry. He can speak Afrikaans - "the white man's other language" - but he uses it only when he speaks to officials $(1978,17)$.

11 It is Roy Wagner's distinction. As opposed to the marked (narrower) sense of culture (literature and the arts), "culture" is used in my essay in the unmarked (broad) sense, to include "science, art, and technology, the sum total of achievements, inventions, and discoveries" (Roy Wagner 1981, 22), "unmarked" to the immense extent that cognitive cultural studies broadens it, viewing culture, as Raymond Williams did, as "a whole way of life" (Zunshine 2010a, 8).

See, for example, Kathrin M. Wagner on Gordimer's "landscape iconography," Lars Engle discussing The Conservationist in the context of the Rev. Henry Callaway's The Religious System of the Amazulu (1993, 95 and on), or Michael Thorpe on how "[t]he ancestor motif centers upon the unknown man who near the beginning is found murdered on Mehring's farm" $(1990,117)$.

13 "Kaffir" used for a long time by white colonizers to refer to black Africans is a cruelly offensive word today.

14 Jan Assmann's categories (2011, 112-113). 
If his intercultural dislike of the Dutch does not show through in his interpersonal handling of the De Beers's visit and he generously lends them what they want before they ask for it, it is because he wants to shake them off as fast as possible. Black foreman Jacobus loathes the Boers more than Mehring does, resents his boss lending De Beer his Toyota pickup and tells Mehring so. And the way Gordimer's Indian immigrants feel in South Africa adds further details to what Vasu Reddy tells us about what South African writers of Indian origin emphasize in their works: "the dehumanizing effects of racial oppression" $(2001,83)$.

Human conversations evolve, John J. Gumperz informs us, along the "culturally possible lines of reasoning" $(1982,160)$. The conversations that apartheid culture makes possible - turning now to the second point of banal and elusive speech acts - are the trivial and evasive communicative routines that follow from what we have just seen in particular, but also from the racialization of intercultural communication in general. Mehring has no doubt that the blacks "are busy complaining about him in the safety of their own language, they retreat into it and they can say what they like" (1978, 75; emphasis in the original); and "[t]he children don't understand the language," English that is $(1978,10)$. Interracial communication between, say, Mehring and Jacobus, is possible only through "the conventions of polite conversation" $(1978,223-224)$. It is always "the usual sort of exchange between his black man and himself" (1978, 58). Between the Boers and Mehring communcation is "the well-regulated demands and responses" $(1978,58)$. When De Beer wants to ask Mehring something, it goes like this: "There has been a whole preamble of small talk about the weather, the drought, the usual thing before getting to the point" $(1978,49)$. Apartheid South Africa may be part of the reader's general knowledge as s/he starts reading The Conservationist but as we read the novel, we gradually acquire the text-specific knowledge that intercultural communication in this racist culture is not really inter and not real communication. Intercultural skills simply mean a skillful manipulation of communicative surfaces as dictated by, and can be expected from, one's (Mehring's, Jacobus's, and the others') position in this particular sociocultural hierarchy. It is Jacobus's position that makes him quite an artist of evasive communication and communicative manoevring. He is "not without sycophancy" in Mehring's presence (Mehring finds, intramentally) (1978, 12); in the presence of others he "agrees with everything that Mehring says, rather than gives an independent answer" $(1978,56)$, although Mehring will soon find, when they are alone, that Jacobus does have an independent view of the matter. But the blacks look up to the black foreman since "they knew Jacobus was the boss of the show, he ran that farm while the white man lived in town" (1978, 37). A careful look at how these two conduct their interpersonal dealings with each other shows that intramentally both argue stubbornly (whether it is the guinea fowl issue or whether they need a fierce dog or not [1978, 32-33]), but 
intermentally the strategy is always clash-avoidance on Jacobus's part, the roundabout method. His disagreement with a negative point Mehring raises is always through a positive idea. This brings us to the matter of discourse, a subject which has been crying for attention in this paper for a while.

\section{Conclusion: Discourse and Narrative Identity}

But it would be sheer tautology to repeat the points already made about how apartheid is a racist discourse, anti-apartheid narratorial feelings are a counterdiscourse, and the characters have their own discourse. What we would capture in our discursive net if cast this way would be only parts (significant constituents, though) of the main discursive concern of the narrative as a whole - of the global narrative discourse.

We can look for The Conservationist's global narrative discourse in the narratorial consciousness. As I claimed elsewhere in a narrato-cultural essay: "a narratorial mind is not simply present in a narrative text, but the text is the content of that mind since what the text contains is the product of a narrator's or an implied author's consciousness" (Abádi-Nagy 2008, 21). And our extradiegetic (external) teller of the tale (Gordimer calls her "objective narrator" as indicated earlier) is an implied-author narrator, who has an anti-apartheid mindset, and that is the cultural determination that produces and rules the Gordimer novel's text (the what of the narrative) and shapes the narrative (the how). Without getting entagled in the intricacies of Seymour Chatman's definitions of content and expression (story and discourse) planes vis-à-vis substance and form,,$^{15}$ I wish to adopt his idea of "deep narrative predicate," which is not the same as (though constructed through a series of) "surface lingusitic predicates" $(1978,146)$. A deep narrative predicate can determine not only longer stretches of narrative, but a whole work, narrated or nonnarrated, directly or in mediated ways, embedded directly or indirectly

15 Above I quoted Gordimer on how the main points the novel is making are "implicit." Where can we look for what is implicit in The Conservationist? It can be found in the narrative discourse, as we process it, in both the narratological and the discourse analysis senses of the term "discourse." And the two are closely interrelated. Ever since Seymour Chatman introduced the distinction between story and discourse - content versus expression (1978, 26 and on) - discourse is the how, the manner as opposed to the story-line, the subject, the what. It is the way as David Herman puts it: it is "the method of narrative presentation," "the mode of telling," "the manner in which those events are organized in the recounting" $(2002,214)$. And by focusing on the expression level of the story or the manner of telling (the narratological sense of discourse), we will be attentive to discourse entities, discourse units, and discourse structure in the discourse-analysis sense. To put it in a more narrative-specific way, in Herman's words elsewhere (based on Catherine Emmott): "narrative can be viewed as a discourse environment in which producers as well as interpreters of stories use many different linguistic resources - or coding strategies - to establish and maintain reference to discourse entitites that interact with one another in narrative-specific ways" $(2003,13)$. 
in narratorial consciousness or/and storyworld character-focalizers. The deep narrative predicate - what can be called narratorial global discourse in the contexts of this paper - was already mentioned above as the widening rift between Mehring's position and the apartheid-driven cognitive architecture that positions him. The Conservationist's mediated discursive point is that such a seemingly unresolvable tension, culminating in a rift, necessarily disjoins a sensitive human individual from his or her own cognitive architecture in a brutally inhuman society, even if that sensitivity is internally half-buried already under the social values that the individual incorporated into his or her own cognitive architecture. This global narrative discourse or deep narrative predicate organizes the how of Gordimer's narrative in the senses Chatman theorizes the how: the "structure of narrative transmission" ("form of expression") and enfolding discourse "manifestations" ("substance of expression") $(1978,26)$. Let it suffice to say, more simply, in the concrete terms of the novel, what the how that Gordimer's deep narrative predicate develops in the novel is: the narrator processes Mehring through a series of events/ actions and recollections (inter- and intramental activities), making him think over who he is, what his position in apartheid society is. After all, as Frantz Fanon asserts relating to (otherwise mainly reacting against) French psychoanalyst Octave Mannoni's ideas: "the problem of colonialism includes not only the interrelations of objective conditions but also human attitudes toward these conditions" (1968, 84). In turn, through Mehring's own narratives that narrativize the formation of his narrative identity, the extradiegetic anti-apartheid narrator herself thinks apartheid-driven South Africa over, adjusting Mehring's perspectival filtering to align the reader with the narratorial vantage point. In a word, the discursive method is mapping socio-cultural cognition here. ${ }^{16}$

If The Conservationist is the cognitive cultural mapping of its deep narrative predicate, the "plot" (not in the usual sense because much more of the novel is stasis than action) will be mental. How? Similarly to the way every single narrative entity (characters, objects, and narrative space ${ }^{17}$ ) is inscribed with the deep narrative predicate, the contextual blocks or discourse units, each and every one of them are also weaving the same global discourse of the narrative, through a series of local discourse contexts. This is yet another (the third), the discourseanalysis sense of "discourse." It is an understanding of a discourse unit which points to a unit of content, perhaps inclusive of subsidiary events and/or changing locations, but remaining inside the same local narrative context (Emmott 1997,

16 It is not identical with "cognitive mapping." The latter is reserved to mean, in a narrower sense: "a mental model in spatial relations;" in the extended sense as used by Marie-Laure Ryan: the readerly construction of narrative space "as a background for the understanding of plot, character motivations, and the moral issues articulated in the text" (Ryan 2003, 215-216).

17 Gordimer's copius descriptions of various aspects of landscape and space thoroughly imbued with thematic concerns and symbolic significance have been given ample treatment in Gordimer criticism. (See Brian Macaskill [1993] and Kathrin M. Wagner [1993].) 
12-13). Our example can be the De Beer family's visit with Mehring as one and the same local discourse context, in spite of the shifts from the Mehring/De Beer interpersonal exchange in Mehring's house to Jacobus and De Beer outside and then the switch to the Jacobus/Mehring confrontation over the De Beer visit. It is also the global narrative discourse which is woven in the discourse structure of the shifting contextual units that the text divides into or is putting itself together through. In our De Beer-visit example the kaffir doll - as only one hint at racial intolerance among the many - is a case in point.

The way global discourse units can be built into multiple local discourse units (contexts) is not only through discourse (deep-predicate) distribution. The narrato-rhetorical purpose is also served by cultural narrato-rhetorhemes ${ }^{18}$ which also shape Mehring's narrative identity. Some of the narrato-rhetorhemes can have global narrative functions, as, most outstandingly, the governing trope of the murdered black stranger does. The dead man highlights the South African social condition that Fanon talks about; very slowly and behaviouristically it also awakens Mehring to realize, at first only very vaguely and then with growing intensity, where he stands with where he is. He senses that "his relation to the land he owns but cannot possess," as Rowland Smith remarks, is "inauthentic," this being "part of Mehring's crisis of consciousness;" and the "internal and imagined" debates with Antonia and Terry become "ultimately destabilizing" $(1993,50)$. Let us add that his attitude towards his own position can at long last take the shape of severing ties with his own position as a farmer at least at the level of a sudden gut-reaction after all those rationalizations.

But the gut-reaction that ensued was also provoked by those rationalizations. We can tell from a series of inferences. That we have to rely on inferences (he is a much more complex socio-cultural construct than his mistress's and his son's simplified views of him could justify) is indicative of the paradox the Mehring-phenomenon revolves around, ultimately: his identity turns out to be, eventually, unnarratable by himself even to himself; yet this becomes the source of the narrativity of such an identity. It speaks to the productivity of cognitive narratology that its methodology made the inference of a cognitive rift in Mehring possible. Since that cognitive rift can be read to be rooted in a sociocultural split in the individual's identity, we

18 The narrato-rhetorical units that I called cultural "narrato-rhetorhemes" in a separate study are narrative units loaded with cultural content and rhetorical purpose, meant to develop and frame the cultural narrative rhetoric. It is rhetorical suasion through culture in the narrative. A narrato-rhetorheme can be a functionally restricted cultural sign or one that encompasses a whole book. Elemental or immensely complex, it can convey overt or covert rhetorical content in the storyworld, on the narratorial discourse level, or anywhere else in the multiple communicative intricacy called narrative fiction. It is by leaving the category undefined in more specific terms that it can retain the flexibility to take in, in an unregulated fashion, the rhetorically marked multiplicity, heteroglossia, and transformations of textual manoeuvres of persuasion; an analytical tool which is hoped to make an intricate narrative "traffic" of discursive communications manageable for theory and criticism. (Cf. Abádi-Nagy 2014, 35-39.) 
can also rephrase our diagnosis of Mehring. Paul Ricoeur's “hermeneutics of the self” $(1994,16)$ posits that " $t$ the narrative constructs the identity of the character, what can be called his or her narrative identity, in constructing that of the story told. It is the identity of the story that makes the identity of the character" (1994, 147-148). And the identity of the story told in The Conservationist describes an individual who lives and behaves as almost a mechanism of a set of "acquired identifications." "To a large extent," Ricoeur goes on to say, “ [...] the identity of a person or a community is made up of these identifications with values, norms, ideals, models, and heroes, in which the person or the community recognizes itself. Recognizing oneself in contributes to recognizing onself by." It is "otherness assumed as one's own” (1994, 121; emphasis in the original). The Mehringphenomenon can be rediagnosed, his narrative identity that his story projects onto the pages of the novel redescribed, then, as the case when the other claims the same: the other of acquired colonialist-apartheid identifications enters into the composition of the same, to produce the concordance of the narrative identity (a clearly negative concordance) that identifies Mehring.

But the identity of all narrative compositions can be described, Ricoeur advises us, not simply as concordance but as "the synthesis of the heterogeneous," a "configuration" of "discordant concordance" $(1994,141)$. His theoretical insight vividly illuminates both the alienated stasis and the rift as well as the slow movement away from stasis that construct Mehring's narrative identity. The discordant element is introduced into concordance with the discovery of the murdered African. The dead stranger slowly activates Mehring's innate self - the innate self of a man who has almost totally become a dead stranger himself by any standards of opennes to human rights and democracy. The circumstance that he is intelligent enough to comprehend what is happening to him and is bent (even if instinctively and reluctantly at first) on expelling as much of the other from the same as he is capable of at the stage where the novel leaves him (or, bent on resisting the other, which other is bent on expelling the same out of him, if you like).

This capability is - if not a resurrection as the black man's is through his reburial - is at least a promise of at least one white man coming to his senses. It is a factor that makes it possible for anti-apartheid Nadine Gordimer to treat a basically despicable character like Mehring with qualified sympathy. Judith Levy rightly points out, "contrary to prevailing critical opinion" that "in the delineation of the protagonist in The Conservationist, the vision of the individual on a personal inner quest has not been wholly superceded by this character's representing and playing out the inevitable destiny of his class and status. Rather, these two visions exist side by side, expressing, perhaps, ambivalence on the part of Gordimer herself” (2006, 103). Except that it remains sympathy that cannot be regarded ambivalence on the novelist's part. Let me grant Gordimer herself the right to decide the issue. In her response to a Peter Marchant interview question she said: Mehring "is just exactly 
the kind of man I hate in South Africa. But, once I began to write about him and got under his skin, I began to understand him better. I don't believe that to understand all is to forgive all. Certainly in a country with conflict like my own, that's a very dangerous attitude. But for a writer, it's absolutely essential to understand all, and once you do, you cannot be entirely unsympathetic” $(1990,259)$.

\section{Works Cited}

Abádi-Nagy, Zoltán. 2008. "Narratorial Consciousness as an Intersection of Culture and Narrative (Case Study: Toni Morrison’s Jazz)." Hungarian Journal of English and American Studies vol. 14 no. 1 (Spring): 21-33.

Abádi-Nagy, Zoltán. 2014. "The Rhetorical Function of Culture in Fictional Narrative: The Cultural Narrato-Rhetorheme." Hungarian Journal of English and American Studies vol. 20 no. 1 (Spring): 29-54.

Assmann, Jan. 2011 [1992, 2007]. Cultural Memory and Early Civilization: Writing, Remembrance, and Political Imagination. Trans. David Henry Wilson. Cambridge: Cambridge University Press. [Originally published as Assmann, Jan. 1992. Das kulturelle Gedächtnis: Schrift, Erinnerung und politische Identität in frühen Hochkulturen. München: Verlag C. H. Beck.]

Barnard, Rita. 2007. Apartheid and Beyond: South African Writers and the Politics of Space. Oxford: Oxford University Press.

Bhabha, Homi K. 1994. The Location of Culture. London and New York: Routledge. Bortolussi, Marisa and Peter Dixon, eds. 2003. Psychonarratology: Foundations for the Empirical Study of Literary Response. Cambridge: Cambridge University Press.

Chatman, Seymour. 1978. Story and Discourse: Narrative Structure in Fiction and Film. Ithaca and London: Cornell University Press.

Clingman, Stephen. 1990. "Deep History.” In Critical Essays on Nadine Gordimer, ed. Rowland Smith, 205-222. Boston: G. K. Hall.

Cooper-Clark, Diana. 1990. “The Clash.” In Conversations with Nadine Gordimer, eds. Nancy Topping Bazin and Marilyn Dallman Seymour, 215-228. Jackson and London: University Press of Missisippi.

Driver, Dorothy. 1990. "Nadine Gordimer: The Politicisation of Women." In Critical Essays on Nadine Gordimer, ed. Rowland Smith, 180-204. Boston: G. K. Hall.

Emmott, Catherine. 1997. Narrative Comprehension: A Discourse Perspective. Oxford and New York: Oxford University Press.

Emmott, Catherine. 2003. "Constructing Social Space: Sociocognitive Factors in the Interpretation of Character Relations." In Narrative Theory and the Cognitive Sciences, ed. David Herman, 295-321. Stanford, CA: CSLI Publications. 
Engle, Lars. 1993. "The Conservationist and the Political Uncanny.” In The Later Fiction of Nadine Gordimer, ed. Bruce King, 91-107. Houndmills, Basingstoke and London: Macmillan.

Fanon, Frantz. 1968 [1967]. Black Skin, White Masks. Trans. Charles Lam Markmann. New York: Grove Press. [Originally published as Fanon, Frantz. 1952. Peau Noire, Masques Blancs. Paris: Editions du Seuil.]

Freeman, Mark. 1993. Rewriting the Self: History, Memory, Narrative. London and New York: Routledge.

Gordimer, Nadine. 1978 [1974]. The Conservationist. Harmondsworth: Penguin Books.

Graesser, A. C., M. Singer and T. Trabasso. 1994. “Constructing Inferences During Narrative Text Comprehension.” Psychological Review vol. 101 no. 3: 371-395.

Gray, Stephen. 1990. "An Interview with Nadine Gordimer.” In Conversations with Nadine Gordimer, eds. Nancy Topping Bazin and Marilyn Dallman Seymour, 176-184. Jackson and London: University Press of Mississippi.

Gross, Terry. 1990. "Fresh Air: Nadine Gordimer.” In Conversations with Nadine Gordimer, eds. Nancy Topping Bazin and Marilyn Dallman Seymour, 306-313. Jackson and London: University Press of Mississippi.

Gumperz, John J. 1982. Discourse Strategies. Studies in Interactional Sociolinguistics 1. Cambridge: Cambridge University Press.

Herman, David. 2002. Story Logic: Problems and Possibilities of Narrative. Lincoln and London: University of Nebraska Press.

Herman, David. 2003. "Introduction." In Narrative Theory and the Cognitive Sciences, ed. David Herman, 1-30. Stanford, CA: CSLI Publications.

Hogan, Patrick Colm. 2010. "On Being Moved: Cognition and Emotion in Literature and Film.” In Introduction to Cognitive Cultural Studies, ed. Lisa Zunshine, 237-256. Baltimore, MD: The Johns Hopkins Press.

Hurwitt, Jannika. 1990. "The Art of Fiction LXXVII: Nadine Gordimer." In Conversations with Nadine Gordimer, eds. Nancy Topping Bazin and Marilyn Dallman Seymour, 127-160. Jackson and London: University Press of Missisippi.

Jahn, Manfred. 2003. “'Awake! Open your eyes!': The Cognitive Logic of External and Internal Stories." In Narrative Theory and the Cognitive Sciences, ed. David Herman, 195-213. Stanford, CA: CSLI Publications.

Levy, Judith. 2006. "Narrative as a Way of Being: Nadine Gordimer's The Conservationist." Partial Answers: Journal of Literature and the History of Ideas vol. 4 no. 2 (June): 103-114.

Macaskill, Brian. 1993. "Placing Spaces: Style and Ideology in Gordimer's Later Fiction." In The Later Fiction of Nadine Gordimer, ed. Bruce King, 59-73. Houndmills, Basingstoke and London: Macmillan. 
Marchant, Peter, Judith Kitchen and Stan Sanvel Rubin. 1990. "A Voice from a Troubled Land. A Conversation with Nadine Gordimer." In Conversations with Nadine Gordimer, eds. Nancy Topping Bazin and Marilyn Dallman Seymour, 253-263. Jackson and London: University Press of Missisippi.

Margolin, Uri. 2003. "Cognitive Science, the Thinking Mind, and Literary Narrative." In Narrative Theory and the Cognitive Sciences, ed. David Herman, 271-294. Stanford, CA: CSLI Publications.

Pettersson, Rose. 1995. Nadine Gordimer's One Story of a State Apart. Uppsala: Acta Universitatis Upsaliensis, Studia Anglistica Upsaliensia 88.

Reddy, Vasu. 2001. "History and Memory: Writing by Indian Authors." In Apartheid Narratives, ed. Nahem Yousaf, 81-99. Amsterdam and New York: Rodopi.

Ricoeur, Paul. 1994 [1992]. Oneself as Another. Trans. Kathleen Blamey. Chicago and London: University of Chicago Press. [Originally published as Ricoeur, Paul. 1990. Soi-méme comme un autre. Paris: Editions de Seuil.]

Ryan, Marie-Laure. 2003. "Cognitive Maps and the Construction of Narrative Space." In Narrative Theory and the Cognitive Sciences, ed. David Herman, 214-242. Stanford, CA: CSLI Publications.

Said, Edward W. 1979 [1978]. Orientalism. New York: Vintage Books.

Schwartz, Pat. 1990. "Interview: Pat Schwartz Talks to Nadine Gordimer." In Conversations with Nadine Gordimer, eds. Nancy Topping Bazin and Marilyn Dallman Seymour, 78-83. Jackson and London: University Press of Missisippi. Smith, Rowland. 1993. "Black and White in Grey: Irony and Judgement in Gordimer's Fiction.” In The Later Fiction of Nadine Gordimer, ed. Bruce King, 45-58. Houndmills, Basingstoke and London: Macmillan.

Thorpe, Michael. 1990. "The Motif of the Ancestor in The Conservationist." In Critical Essays on Nadine Gordimer, ed. Rowland Smith, 116-123. Boston: G. K. Hall.

Wagner, Kathrin M. 1993. "Landscape Iconography in the Novels of Nadine Gordimer.” In The Later Fiction of Nadine Gordimer, ed. Bruce King, 74-88. Houndmills, Basingstoke and London: Macmillan.

Wagner, Roy. 1981. The Invention of Culture. Revised and expanded edition. Chicago and London: The University of Chicago Press.

Zunshine, Lisa. 2006. Why We Read Fiction: Theory of Mind and the Novel. Columbus, OH: The Ohio State University Press.

Zunshine, Lisa. 2010a. "Introduction: What Is Cognitive Cultural Studies?” In Introduction to Cognitive Cultural Studies, ed. Lisa Zunshine, 1-33. Baltimore, MD: The Johns Hopkins Press.

Zunshine, Lisa. 2010b. "Theory of Mind and Experimental Representations of Fictional Consciousness." In Introduction to Cognitive Cultural Studies, ed. Lisa Zunshine, 193-213. Baltimore, MD: The Johns Hopkins Press. 